\title{
GAMBARAN STATUS BESI PADA PASIEN PENYAKIT GINJAL KRONIK YANG MENJALANI HEMODIALISIS
}

\author{
${ }^{1}$ Kurniawan K. Patambo \\ ${ }^{2}$ Linda W. A. Rotty \\ ${ }^{2}$ Stella Palar
}

\author{
${ }^{1}$ Kandidat Skripsi Fakultas Kedokteran Universitas Sam Ratulangi Manado \\ ${ }^{2}$ Bagian Ilmu Penyakit Dalam Fakultas Kedokteran Universitas Sam Ratulangi Manado \\ Email: kurniawankombara@yahoo.com
}

\begin{abstract}
Chronic Kidney Disease (CKD) is a process of patofisiologis with multiple etiology, resulting in decline kidney function that is progressive and generally ending with kidney failure. The incidence of the patients with CKD in developing countries, is estimated to be around 40-60 cases per 1 million citiziens per year. The World Health Organization (WHO) estimated that there will be an increase in patients with kidney disease in Indonesia as much as $41.4 \%$ between 1995-2025. In Indonesia, from data in some parts of Nephrology, estimated incidence of CKD range 100-150 per 1 million citiziens. This research aims to know the description of iron status in Chronic Kidney Disease who undergoing Hemodialysis in Intalation of Hemodialysis was BLU Prof. Dr. R.D. Kandou Hospital. Method: This study uses descriptive retrospective method based on primary data from research period November 2013 - December 2013 in the Installation of Hemodialysis was BLU. Prof. Dr. R. D. Kandou Hospital. Research variables used are age, sex, the results of the laboratory test, the cause of CKD, undergoing long-term of Hemodialysis. Result: The results are from 57 total patient who included in research criterion there 41 (72\%) men and 16 (28\%) woman, based on the age group, group of age 41-64 38 (67\%), the distribution of laboratory results based on hemoglobin levels in men at levels of 8-8.9 g/ dL, 15 (37\%), as well as the women in the highest levels of hemoglobin levels of 8-8.9 g/ dL 5 (32\%), based on hematocrit levels in men - most men in levels of 24-26.9\% 14 (34\%), and women most at levels of 21-23.9\% 5 (32\%), based on the highest value of serum iron value of 59-158 ug/ dL 33 (58\%), based TIBC value most in the value $<250$ ug / dL 52 (91\%), based on the highest value of transferrin saturation values $>50 \% 27$ (48\%), based on the most cause of CKD due Nefrosclerosis Hypertension 56 (98\%). Conclusion: On this research most on sex men and age group 20-64.
\end{abstract}

Keywords: Chronic Kidney Disease, Iron serum, TIBC, Transferrin saturation.

\begin{abstract}
Abstrak: Penyakit ginjal kronik (PGK) merupakan suatu proses patofisiologis dengan etiologi yang beragam, mengakibatkan penurunan fungsi ginjal yang progresif dan pada umumnya berakhir dengan gagal ginjal. Insidens penderita PGK di negara-negara berkembang, diperkirakansekitar 40 - 60 kasus perjuta penduduk per tahun. World Health Organization (WHO) memperkirakan akan terjadi peningkatan pasien dengan penyakit ginjal di Indonesia sebesar 41,4\% antara tahun 1995-2025. Di Indonesia, dari data di beberapa bagian nefrologi, diperkirakan insidens PGK berkisar 100-150 per 1 juta penduduk.Penelitian ini bertujuan untuk mengetahui gambaran status besi pada Penyakit Ginjal Kronik yang menjalani Hemodialisis di Instalasi Tindakan Hemodialisis BLU RSUP Prof. Dr. R.D. Metode: Penelitian ini menggunakan metode retrospektif deskriptif berdasarkan data primer pada periode November 2013 - Desember 2013 di Instalasi Tindakan Hemodialisis BLU RSUP. Prof. Dr. R. D. Kandou dengan variabel penelitian yang digunakan yaitu umur, jenis kelamin, hasil laboratorium, penyebab PGK, lama menjalani Hemodialisis. Hasil: Hasil dari peneltian ini adalah dari 57 pasien yang memenuhi kriteria inklusi berdasarkan jenis kelamin, laki - laki 41 (72\%) dan perempuan 16 (28\%), berdasarkan kelompok umur terbanyak pada usia 41-64 tahun 38 (67\%), distribusi hasil laboratorium berdasarkan kadar hemoglobin, laki - laki terbanyak pada kadar 8-8,9 g/dL 15 (37\%), sama halnya pada perempuan 5 (32\%), berdasarkan kadar hematokrit pada laki - laki terbanyak pada kadar 24-26,9\% 14 (34\%), dan perempuan pada kadar 21 - 23,9\% 5 (32\%), berdasarkan nilai serum iron terbanyak nilai 59-158 ug/dL 33 (58\%), berdasarkan nilai TIBC terbanyak nilai <250 ug/dL 52 (91\%), berdasarkan nilai saturasi transferin terbanyak nilai >50\% 27 (48\%), berdasarkan penyebab PGK terbanyak akibat Hipertensi nefrosklerosis 56 (98\%). Simpulan:pada penelitian ini terbanyak pada jenis kelamin laki - laki dan kelompok umur 20 - 64 tahun. Kata kunci: Penyakit ginjal kronik, Serum iron, TIBC, Saturasi transferin.
\end{abstract}


Penyakit ginjal kronik (PGK) merupakan suatu proses patofisiologis dengan etiologi yang beragam, mengakibatkan penurunan fungsi ginjal yang progresif dan pada umumnya berakhir dengan gagal ginjal. ${ }^{1} \mathrm{Di}$ Amerika Serikat jumlah pasien penyakit ginjal kronik terus meningkat setiap tahunnya, dari data tahun 1991 terdapat 209.000 orang menderita PGK hingga tahun 2004 terdapat 472.000 orang yang menderita PGK, dari data tersebut prevalensi penyakit ginjal kronik meningkat hingga 43\% selama dekade tersebut. ${ }^{2}$ Dari hasil statistik di Amerika Serikat pada tahun 2000-2008, insiden penyakit ginjal kronik sangat meningkat pada usia 65 tahun keatas yaitu mencapai 18,8-24,5\% dibandingkan dengan pada usia 20-64 tahun insiden PGK hanya mencapi $0,5 \% .^{3}$

Pada penyakit ginjal kronik Kadar hemoglobin (HB) yang rendah atau anemia merupakan kondisi yang umum ditemukan, yang mana prevalensiserta keparahannya meningkat sesuai dengan peningkatan keparahan dari PGK. ${ }^{4}$ Dengan kata lain, anemia berkembang pada awal perjalanan PGK dan hampir mengenai seluruh pasien PGK stadium akhir. ${ }^{5}$

Defisiensi besi merupakan penyebab anemia yang kedua pada pasien dengan PGK. Penyebab utama defisiensi besi pada PGK adalah asupan yang kurang, gangguan absorpsi, perdarahan kronik, inflamasi atau infeksi, serta peningkatan kebutuhan besi selama koreksi anemia dengan terapi ESA(Eritropoetin Stimulating Agent), oleh karena itu anemia akan sangat nyata pada PGK baik yang menjalani terapi eritropoetin maupun yang melakukan hemodialisis. ${ }^{1}$

Banyaknya jumlah kasus penyakit Ginjal Kronik (PGK) yang melakukan hemodialisis, sehingga peneliti merasa tertarik untuk melakukan penelitian ini. Di mana penelitian ini, akan dilakukan pengambilan data primer pasien Penyakit Ginjal Kronik yang menjalani Hemodialisis di Instalasi Tindakan hemodialisis BLU RSU Prof. Dr. R.D. Kandou Manado periode November 2013 - Desember 2013.

\section{METODE PENELITIAN}

Jenis penelitian yang dilakukan bersifat retrospektif deskriptif berdasarkan data primer dari penelitian selama dua bulan di Instalasi Tindakan Hemodialisis. Penelitian dilakukan di Instalasi Tindakan Hemodialisis BLU RSUP Prof. Dr. R. D. Kandou Manado pada bulan November 2013Desember 2013. Subjek penelitian ini adalah semua pasien PGK yang dirawat jalan di bagian Penyakit Dalam RSU Prof. Dr. R.D. Kandou Manado Periode November 2013Desember 2013.

\section{Cara kerja}

\section{Pengumpulan Data}

Pengumpulan data dilakukan dengan melihat catatan rekam medik penderita dengan diagnosis penyakit ginjal kronik (PGK) yang dirawat di Bagian Penyakit Dalam RSU Prof. Dr. R. D. Kandou Manado periode Januari 2013-Agustus 2013.

\section{Pengolahan Data}

Pengolahan data di lakukan secara manual dan mengunakan computer data yang ada dihitung dalam bentuk distribusi frekuensi.

\section{HASIL PENELITIAN}

Hasil penelitian retrospektif yang dilakukan di BLU. RSUP Prof. R. D. Kandou Manado periode November 2013 Desember 2013, didapatkan pasien yang menderita penyakit ginjal kronik yang melakukan hemodialisis:

Tabel 1. Distribusi pasien PGK yang melakukan hemodialisis berdasarkan jenis kelamin

\begin{tabular}{ccc}
\hline \multirow{2}{*}{ Jenis Kelamin } & \multicolumn{2}{c}{ Jumlah Pasien } \\
\cline { 2 - 3 } & $\mathbf{n}$ & $\mathbf{( \% )}$ \\
\hline Laki - laki & 41 & 72 \\
Perempuan & 16 & 28 \\
\hline Total & 57 & 100 \\
\hline
\end{tabular}


Patambo, Rotty, Palar; Gambaran Status Besi pada Pasien Penyakit Ginjal Kronik...

Berdasarkan tabel diatas (Tabel 1), dapat kita lihat bahwa pasien PGK yang melakukan hemodialisis banyak terjadi pada pasien dengan jenis kelamin laki-laki yang berjumlah 41 pasien (72\%), sedangkan yang perempuan berjumlah 16 pasien (28\%).

Tabel 2. Distribusi pasien PGK yang melakukan hemodialisis berdasarkan kelompok umur

\begin{tabular}{ccc}
\hline \multirow{2}{*}{ Kelompok Umur } & \multicolumn{2}{c}{ Jumlah Pasien } \\
\cline { 2 - 3 } & $\mathbf{n}$ & $\mathbf{( \% )}$ \\
\hline$<20$ & 0 & 0 \\
$21-40$ & 8 & 14 \\
$41-64$ & 38 & 67 \\
$>65$ & 11 & 19 \\
\hline Total & 57 & 100 \\
\hline
\end{tabular}

Berdasarkan Tabel diatas, dapat kita lihat bahwa pasien PGK yang melakukan hemodialisis paling banyak terjadi pada kelompok umur 41-64 tahun yaitu sebanyak 38 pasien (67\%), diikuti umur 20-40 sebanyak 8 pasien (14\%), diikuti umur >65 tahun sebanyak 11 pasien (19\%), dan yang terakhir pada umur $<20$ tahun tidak ditemukan pasien.

Tabel 3. Distribusi pada pasien PGK laki-laki yang melakukan hemodialisis berdasarkan kadar hemoglobin

\begin{tabular}{ccc}
\hline $\begin{array}{c}\text { Kadar } \\
\text { Hemoglobin } \\
\text { (g/dL) }\end{array}$ & \multicolumn{2}{c}{ Jumlah Pasien } \\
\cline { 2 - 3 }$<6,9$ & $\mathbf{n}$ & $\mathbf{( \% )}$ \\
$7-7,9$ & 3 & 5 \\
$8-8,9$ & 15 & 7 \\
$9-9,9$ & 11 & 37 \\
$10-10,9$ & 5 & 27 \\
$11-13$ & 5 & 12 \\
\hline Total & 41 & 100 \\
\hline
\end{tabular}

Berdasarkan Tabel diatas, dapat dilihat bahwa pasien PGK khususnya pada lakilaki yang melakukan hemodialisis memiliki kadar hemoglobin paling banyak pada kadar 8-8,9 sebanyak 15 pasien (37\%), diikuti kadar hemoglobin 9-9,9 sebanyak 11 pasien (27\%), kadar hemoglobin 10-10,9 dan 11-13 yaitu masing-masing sebanyak 5 pasien (12\%), kadar hemoglobin 7-7,9 sebanyak 3 pasien (7\%) dan yang terakhir pada kadar hemoglobin $<6,9$ sebanyak 2 pasien (5\%).

Tabel 4. Distribusi pasien PGK perempuan yang melakukan hemodialisis berdasarkan kadar hemoglobin

\begin{tabular}{ccc}
\hline Kadar & \multicolumn{2}{c}{ Jumlah Pasien } \\
\cline { 2 - 3 } $\begin{array}{c}\text { Hemoglobin } \\
(\mathbf{g} / \mathbf{d L})\end{array}$ & $\mathbf{n}$ & $\mathbf{( \% )}$ \\
\hline$<6,9$ & 1 & 6 \\
$7-7,9$ & 4 & 25 \\
$8-8,9$ & 5 & 32 \\
$9-9,9$ & 4 & 25 \\
$10-10,9$ & 1 & 6 \\
$>11$ & 1 & 6 \\
Total & 16 & 100 \\
\hline
\end{tabular}

Berdasarkan Tabel diatas, dapat dilihat bahwa pasien PGK khususnya pada perempuan yang melakukan hemodialisis memiliki kadar hemoglobin paling banyak pada kadar 8-8,9 sebanyak 5 pasien (32\%), diikuti kadar hemoglobin 7-7,9 dan 9-9,9 yaitu masing-masing sebanyak 4 pasien (25\%), dan yang terakhir pada kadar hemoglobin <6,9, 10-10,9 dan >11 yaitu masing-masing 1 pasien (6\%).

Tabel 5. Distribusi pasien laki-laki PGK yang melakukan hemodialisis berdasarkan kadar hematokrit

\begin{tabular}{ccc}
\hline \multirow{2}{*}{ Kadar } & \multicolumn{2}{c}{ Jumlah Pasien } \\
\cline { 2 - 3 } Hematokrit (\%) & $\mathbf{n}$ & $\mathbf{( \% )}$ \\
\hline$<20,9$ & 2 & 5 \\
$21-23,9$ & 8 & 19 \\
$24-26,9$ & 14 & 34 \\
$27-29,9$ & 9 & 22 \\
$30-32,9$ & 4 & 10 \\
$>33$ & 4 & 10 \\
\hline Total & 41 & 100 \\
\hline
\end{tabular}


Berdasarkan Tabel 5, dapat kita lihat bahwa pasien PGK khususnya pada lakilaki yang melakukan hemodialisis memiliki kadar hematokrit paling sering pada kadar 24-26,9 sebanyak 14 pasien (34\%), diikuti kadar 27-29,9 sebanyak 9 pasien (22\%), kadar 21-23,9 sebanyak 8 pasien (19\%), kadar 30-32,9 dan >33 masing-masing sebanyak 4 pasien (10\%) dan yang terakhir pada kadar hematokrit <20,9 sebanyak 2 pasien (5\%).

Tabel 6. Distribusi pasien PGK perempuan yang melakukan hemodialisis berdasarkan kadar hematokrit

\begin{tabular}{ccc}
\hline Kadar & \multicolumn{2}{c}{ Jumlah Pasien } \\
\cline { 2 - 3 } Hematokrit (\%) & $\mathbf{n}$ & $\mathbf{( \% )}$ \\
\hline$<20,9$ & 2 & 12 \\
$21-23,9$ & 5 & 32 \\
$24-26,9$ & 4 & 25 \\
$27-29,9$ & 3 & 19 \\
$30-32,9$ & 1 & 6 \\
$>33$ & 1 & 6 \\
\hline Total & 16 & 100 \\
\hline
\end{tabular}

Berdasarkan Tabel 6, dapat dilihat bahwa pasien PGK khususnya pada perempuan yang melakukan hemodialisis memiliki kadar hematokrit paling sering pada kadar 21-23,9 sebanyak 5 pasien (3\%), diikuti kadar 24-26,9 sebanyak 4 pasien (25\%), kadar 27-29,9 sebanyak 3 pasien (19\%), kadar <20,9 sebanyak 2 pasien (12\%), dan yang terakhir pada kadar hematokrit 30-32,9 dan >33 masing-masing sebanyak 1 pasien (6\%).

Tabel 7. Distribusi pasien PGK yang melakukan hemodialisis berdasarkan nilai serum iron

\begin{tabular}{ccc}
\hline \multirow{2}{*}{$\begin{array}{c}\text { Nilai serum } \\
\text { iron (ug/dL) }\end{array}$} & \multicolumn{2}{c}{ Jumlah Pasien } \\
\cline { 2 - 3 } & $\mathbf{n}$ & $\mathbf{( \% )}$ \\
\hline$<59$ & 14 & 24 \\
$59-158$ & 33 & 58 \\
$>158$ & 10 & 18 \\
\hline Total & 57 & 100 \\
\hline
\end{tabular}

Berdasarkan Tabel 7, dapat dilihat bahwa pasien PGK yang melakukan hemodialisis memiliki nilai serum iron paling sering pada nilai 59-158 sebanyak 33 pasien (58\%), diikuti nilai <59 sebanyak 14 pasien (24\%), dan yang terakhir pada nilai serum iron $>150$ sebanyak 10 pasien (18\%).

Tabel 8. Distribusi pasien PGK yang melakukan hemodialisis berdasarkan nilai TIBC

\begin{tabular}{ccc}
\hline \multirow{2}{*}{$\begin{array}{c}\text { Nilai TIBC } \\
\text { (ug/dL) }\end{array}$} & \multicolumn{2}{c}{ Jumlah Pasien } \\
\cline { 2 - 3 }$<250$ & 52 & $\mathbf{( \% )}$ \\
$250-400$ & 5 & 91 \\
$>400$ & 0 & 9 \\
\hline Total & 57 & 100 \\
\hline
\end{tabular}

Berdasarkan Tabel 8, dapat kita lihat bahwa pasien PGK yang melakukan hemodialisis memiliki nilai TIBC paling banyak pada nilai $<250$ sebanyak 52 pasien (91\%), diikuti nilai 250 - 400 sebanyak 5 pasien (9\%), dan yang terakhir nilai $>400$ tidak ada.

Tabel 9. Distribusi Pasien PGK yang melakukan hemodialisis berdasarkan nilai saturasi transferin

\begin{tabular}{ccc}
\hline Nila Saturasi & \multicolumn{2}{c}{ Jumlah Pasien } \\
\cline { 2 - 3 } Transferin (\%) & $\mathbf{n}$ & $\mathbf{( \% )}$ \\
\hline$<20$ & 6 & 10 \\
$20-50$ & 24 & 42 \\
$>50$ & 27 & 48 \\
\hline Total & 57 & 100 \\
\hline
\end{tabular}

Berdasarkan Tabel 9, dapat kita lihat bahwa pasien PGK yang melakukan hemodialisis memiliki nilai saturasi transferin paling banyak pada nilai $>50$ sebanyak 27 pasien (48\%), diikuti nilai 2050 sebanyak 24 pasien (42\%), dan yang terakhir nilai <20 sebanyak 6 pasien (10\%). 
Patambo, Rotty, Palar; Gambaran Status Besi pada Pasien Penyakit Ginjal Kronik...

\section{BAHASAN}

Pada penelitian yang bersifat retrospektif yang dilakukan di BLU. RSUP. Prof. R. D. Kandou Manado periode November 2013 - Desember 2013, didapatkan pasien yang menderita penyakit ginjal kronik yang melakukan hemodialisis sebanyak 57 pasien. Pasien dengan jenis kelamin laki-laki berjumlah 41 pasien (72\%), sedangkan yang perempuan berjumlah 16 pasien (28\%). Sama halnya dengan penelitian yang dilakukan oleh Hanifa dkk, ${ }^{6}$ yang mendapatkan pasien PGK lebih banyak didapatkan pada pasien laki-laki. Pada data umur pasien, yang menunjukkan angka PGK berdasarkan kelompok umur terbanyak menderita PGK adalah kelompok umur 4164 tahun, berjumlah 38 pasien, sama halnya dengan penelitian yang dilaku-kan oleh Hidayati dkk. ${ }^{7}$ Hal ini terjadi karena faktor laju filtrasi glomerulus menurun dalam proses penuaan. Penurunan LFG menyebabkan semakin sedikit neuron yang berfungsi, termasuk fungsi dalam produksi hormon eritropoetin yang berakibat pada terjadinya anemia, walaupun penyebab pada anemia pada PGK sendiri multifactorial. ${ }^{8}$

Terdapat 41 orang laki-laki dan 15 orang perempuan memiliki kadar $\mathrm{Hb}$ di bawah nilai normal, hal ini memperlihatkan bahwa sebagian besar pasien PGK mengalami anemia. Hal ini sesuai dengan penelitian yang dilakukan oleh Ombuh dkk bahwa didapatkan hampir seluruh pasien PGK memiliki $\mathrm{Hb}$ yang rendah. Hal ini didukung oleh teori yang mengatakan bahwa pada PGK terjadi anemia akibat kurangnya produksi hormon eritropoetin yang merangsang produksi sel darah merah di sumsum tulang. ${ }^{9}$

Pada penelitian ini didapatkan 33 pasien yang memiliki nilai serum iron normal, 14 pasien memiliki nilai serum iron menurun, dan 10 pasien sisanya memiliki serum iron yang meningkat. Hal ini sesuai dengan penelitian yang dilakukan Ombuh dkk bahwa pasien dengan serum iron normal adalah yang terbanyak. ${ }^{9}$

Pada penelitian ini didapatkan bahwa pasien PGK yang melakukan hemodialisis banyak yang memiliki nilai TIBC menurun yaitu sebanyak 52 pasien.Sisanya, 5 pasien memiliki nilai TIBC yang normal.Hal ini sesuai dengan penelitian yang dilakukan Ombuh dkk bahwa pasien dengan nilai TIBC menurun lebih banyak dibandingkan nilai TIBC normal. TIBC yang menurun pada PGK dapat disebabkan karena meningkatnya feritin atau dapat terjadi pada anemia penyakit kronis yang terjadi inflamasi. ${ }^{9}$

Pada penelitian ini didapatkan nilai saturasi transferin paling banyak dimiliki oleh pasien PGK dengan nilai $>50$ sebanyak 27 pasien (48\%) yang berarti saturasi transferin meningkat, diikuti nilai 20-50 sebanyak 24 pasien (42\%), dan yang terakhir nilai <20 sebanyak 6 pasien $(10 \%)$. Hal ini tidak sesuai dengan penelitian yang dilakukan oleh Ombuh dkk bahwa pasien dengan nilai saturasi transferin normal adalah yang terbanyak.Peningkatan saturasi transferin didalam tubuh dapat diakibatkan karena penggunaan terapi EPO yang berlebihan sehingga terjadi penumpukan besi di dalam tubuh yang mengakibatkan peningkatan nilai saturasi transferin. ${ }^{10}$

\section{SIMPULAN}

Dari hasil penelitian dan pembahasan dapat ditarik kesimpulan sebagai berikut

1. Jumlah pasien PGK di BLU RSUP Prof. R. D. Kandou Manado periode November 2013-Desember 2013 adalah 57 pasien.

2. Pasien PGK terbanyak berjenis kelamin laki-laki dan kelompok usia terbanyak adalah 20-64 tahun.

3. Terdapat 33 pasien (58\%) yang memiliki serum iron normal

4. Terdapat 52 pasien (91\%) yang memiliki nilai TIBC rendah

5. Terdapat 27 pasien yang memiliki nilai saturasi transferin meningkat

\section{DAFTAR PUSTAKA}

1. Ketut Suwitra. Buku Ajar Ilmu Penyakit Dalam. Jakarta: Interna Publishing, 2009; h.35-1040.

2. Josef C, Elizabeth S, Lesley A, Jane M, John W, Paul E, et al. Prevalence of chronic kidney disease in the united states. Journal 
American medical Association. 2007; 298:17

3. National Kidney and Urologic Diseases Information Clearinghouse.Kidney Desease Statistics for The United States. Juni 2010 [10 okt.2013]. Tersedia dari: http://kidney.niddk.nih.gov/kudiseases/pubs/ kustats/

4. Brunelli SM, Berns JS. Anemia in chronic kidney disease and end-stage renal disease. Nephrologyround.2009; Volume 7 , Issue 8.

5. National Kidney Foundation. KDOQI Clinical Practice Guidelines and Clinical Practice Recommendations for Anemia in Chronic Kidney Disease. AJKD Vol 47, No 5, Suppl 3, May 2006.

6. Hanifa. Prevalensi hipertensi sebagai penyebab penyakit ginjal kronik di unit hemodialisis jurnal Universitas Sumatra Utara. 2009.
7. Hidayati T, Kushadiwijaya H,Suhardi, hubungan antara hipertensi, merokok dan minuman suplemen energi dan kejadian penyakit ginjal kronik. Jurnal Universat Muhamadiyah Yogyakarta. 2008.

8. Ayu Nyoman, Suega Ketut, Widiana Gede. Hubungan Antara Beberapa Parameter Anemia Dan Laju Filtrasi Glomerulus Pada Penyakit Ginjal Kronik Pradialisis; 2010

9. Ombuh. Status Besi Pada Pasien Penyakit Ginjal Kronik. Jurnal Universitas samratulangi. 2012

10. Alan B, Janet K, Alan R, Lily W, Wolfgang $\mathrm{C}$, et al. Infection Risk with Blolus maintenance Iron Suppllementation in Hemodialysis Patients. Journal of The American Society Of Nephrology. 2013; Volume 24 No. 7 